\title{
PERILAKU VIRTUAL REMAJA: STRATEGI COPING, HARGA DIRI, DAN PENGUNGKAPAN DIRI DALAM JEJARING SOSIAL ONLINE
}

\author{
Naufal Mafazi, Fathul Lubabin Nuqul \\ Fakultas Psikologi Universitas Islam Negeri Maulana Malik Ibrahim Malang \\ J1 Gajayana 50 Malang \\ lubabin_nuqul@uin-malang.ac.id
}

\begin{abstract}
Teenager's activities in the online social networks, influenced by the nature of teenager's characteristic who tends to look for a good impression from others. This study examined the effects of coping strategies and self-esteem on the teenagers' self-disclosure on online social networking. In total, 185 adolescents participated the study; they were identified using the purposive sampling. The sample characteristics were having a social media account and an active user of social media. The Revised Self-Disclosure Scale, the Self-Esteem Scale, and the Ways of Coping Checklist were used to collect data. The results of regression analysis showed that there is a positive and significant correlation of coping strategies and self-esteem on adolescents' disclosure in online social networking.
\end{abstract}

Keywords: online social network; self-disclosure; self- esteem; coping strategy

\begin{abstract}
Abstrak
Aktivitas remaja di jejaring sosial online dipengaruhi oleh sifat dasar remaja yang berusaha ingin dinilai positif oleh orang lain. Penelitian ini bertujuan menguji pengaruh strategi coping dan harga diri terhadap pengungkapan diri remaja di jejaring sosial online pada 185 remaja, yang diambil secara purposive sampling, dengan ciri mempunyai akun sosial media dan aktif menggunakannya. Instrumen yang digunakan adalah Skala Pengungkapan Diri (Revised Self-Disclosure Scale), Skala Harga Diri (Self-esteem Scale) dan Skala Strategi Coping (The Ways of Coping Checklist). Analisis data penelitian ini menggunakan analisis regresi. Hasil penelitian ini menemukan bahwa terdapat pengaruh positif strategi coping dan harga diri terhadap pengungkapan diri remaja di jejaring sosial online.
\end{abstract}

Kata kunci: media jejaring sosial online; pengungkapan diri; harga diri; strategi coping

\section{PENDAHULUAN}

Masyarakat pada saat ini telah dihadapkan pada era kemajuan ilmu pengetahuan alam dan teknologi. Salah satu bidang teknologi yang berkembang pesat saat ini adalah teknologi informasi dan komunikasi. Perubahan terjadi dalam bentuk komunikasi dari komunikasi tatap muka menjadi komunikasi termediasi oleh teknologi. Penikmatnya pun beragam dari kalangan usia muda hingga tua.

Tak terkecuali para remaja sebagai pengguna jejaring sosial online dengan intensitas tinggi. Penggunaan jejaring sosial online yang tergolong tinggi atau heavy users adalah penggunaan yang menghabiskan waktu lebih dari 40 jam perbulan (Ariani, dkk, 2013).

Sayangnya tingginya intensitas pengguna jejaring sosial online tidak dibarengi oleh kesadaran remaja dalam berjejaring sosial online. Hanya sedikit yang membuka jejaring sosial online untuk belajar, membaca informasi dan mencari berita yang otoritatif. Survey menunjukan bahwa 95\% remaja dengan rentang usia $12-17$ tahun aktif secara online dan $81 \%$ remaja menggunakan situs jejaring sosial online. Ada $77 \%$ remaja aktif dan menggunakan 
Facebook, dan $24 \%$ menggunakan twitter. Aktifitas remaja selama aktif dalam jejaring sosial online diantaranya adalah memasang foto pada akun jejaring sosial online, memposting nama sekolah, menempel kota asal, memberitahu nama asli, memposting kesukaan seperti film, musik dan buku, memposting tanggal lahir, memposting status hubungan pacaran, dan memposting video tentang diri (Madden,dkk, 2013).

Remaja menurut Erikson adalah masa pencarian identitas diri, mencoba hal baru yang sesuai dengan dirinya (Santrock, 2012). Dapat ditinjau dari banyaknya penggunaan jejaring sosial online yang dimiliki. Mayoritas setiap remaja memiliki empat hingga lebih akun jejaring sosial online (Buntaran \& Helmi, 2015).

Berhubungan dengan orang lain dijejaring sosial online yang dilakukan remaja melibatkan proses pengungkapan diri. Menginformasikan segala tentang diri kepada semua orang menurut Journard (dalam Gainau, 2008) adalah pengungkapan diri. Pengungkapan diri di jejaring sosial online seperti, memberikan ucapan selamat, pujian, dan motivasi. Hal tersebut karena pengungkapan positif dapat memberikan manfaat pada peningkatan kesehatan fisik dan mental serta mengungkapkan pengalaman emosional sehingga dapat mengatur ulang pikiran dan perasaan tentang pengalaman traumatik atau hambatan yang tersembunyi dalam pikiran individu (Paramithasari \& Dewi, 2013)

Akan tetapi tidak selamanya pengungkapan mempunyai efek positif. Mengungkapkan diri di jejaring sosial online seperti mencela orang lain, berkata kotor, melakukan agresi virtual demi kepentingan seseorang, tergolong dalam pengungkapan negatif. Hal ini juga disampaikan oleh Kuss dan Griffiths (2011) pengungkapan negatif dapat berakibat pada penolakan dari orang lain, bahkan dapat dicemooh, dihindari dan dikucilkan dari pergaulan sosial sehingga muncul kesulitan dalam diri. Penggunaan jejaring sosial online berpotensi disalahgunakan sebagai alat untuk mencemooh, melakukan stalking, dan bullying (Hogben, 2007), jika tidak dilakukan dengan hati-hati. Sayangnya hampir 75 juta pengguna internet di Indonesia dan usia antara 12 sampai 18 tahun tercatat sebagai kelompok yang paling sering menggunakan internet. Jumlah ini tidak diimbangi dengan pengawasan orang dewasa, baik guru maupun orang tua, terhadap pengguna internet di usia remaja ini, secara memadai. Kondisi ini menjadi sangat beresiko (Berita satu.com, diakses tahun 2016).

Di sisi lain pengungkapan diri di jejaring sosial online yang dilakukan oleh remaja karena memang merasa ingin dinilai dan diperhatikan oleh orang lain. Penilaian atau evaluasi orang lain terhadap diri remaja menentukan harga diri baik positif atau negatif (Sarwono \& Meinarno, 2015). Artinya, terdapat hubungan antara selfesteem dengan self-disclosure pada remaja dijejaring sosial online.

Remaja dengan harga diri rendah merasa rendah diri, sering memilih tujuan yang tidak realistis, pesimis, dan selalu negatif pada masa lalu (Taylor, dkk, 2012). Seseorang yang memiliki tingkat selfesteem rendah cenderung sering mengupdate status negatif seperti mengenai pasangan romantis, mencari perhatian (attention-seeking) dan pengakuan (validation), menjelaskan kecenderungan mereka yang tinggi untuk memperbaharui (update) status mereka mengenai pencapaian mereka (Dhani, 2015).

Remaja dengan harga diri tinggi lebih dapat pemahaman yang jelas, tujuan yang jelas, wawasan yang luas, dan menikmati pengalaman yang positif. Sehingga intensitasnya dalam mengungkapkan diri di jejaring sosial online rendah dan bentuk pengungkapannya cenderung positif dijejaring sosial online. Senada dengan 
penelitian Varnali \& Toker (2015) menemukan bahwa orang-orang dengan harga diri tinggi cenderung mengungkapkan lebih sedikit, tetapi lebih jujur dalam mengungkapkan.

Alasan remaja mengungkapkan diri erat kaitannya dengan remaja mengekspresikan dirinya. Mengekspresikan perasaan dapat mengurangi stres (Taylor, Peplau, \& Sears, 2012). Sedangkan upaya remaja untuk mengelelola situasi yang membebani, memperluas usaha untuk memecahkan masalah-masalah hidup, dan berusaha untuk mengatasi atau mengurangi stres menurut Santrock (2007) merupakan sebuah coping.

Seseorang dengan kecemasan dan tekanan yang tinggi lebih besar mengungkapkan menggunakan jejaring sosial online Facebook sebagai media untuk mengatasinya. Sedangkan seseorang yang bahagia, kurang sering menggunakan jejaring sosial online Facebook. Hal ini menunjukan bahwa seseorang yang mendapat masalah lebih besar frekuensinya mengungkapkan lebih intens dengan jejaring sosial online (Arseneault, 2012)

Penelitian yang dilakukan Griffiths (2000) juga menguatkan hipotesis mengenai pengaruh coping, harga diri dan pengungkapan diri. Ditemukan bahwa seseorang yang menggunakan internet untuk tujuan coping dan menetralkan hubungan yang kurang adekuat seperti hilangnya dukungan sosial di kehidupan nyata, harga diri yang rendah, dan penilaian negatif tentang fisiknya. Penggunaan internet cenderung menggunakan internet sebagai alat utama untuk mengadakan kontak sosial dan menjadikan internet sebagai sebuah alternatif realitas berbasis tulisan yang penggunanya mampu membenamkan diri dengan menerima identitas personal dan sosial untuk membuat individu merasa lebih baik karena merasa mendapat reward psikologis yang tinggi.
Banyaknya fenomena remaja saat ini yang berani mengungkapkan dirinya secara detail kehidupannya dengan mengungkapkan kebenciannya, kekesalan, kesenangan, motivasi. Seakan-akan remaja tidak memikirkan dampak dari pengungkapan diri mereka di jejaring sosial online. maka dari itu peneliti ingin mengetahui bentuk dan intensitas remaja mengungkapkan diri di jejaring sosial online, bentuk coping yang dilakukan remaja dijejaring sosial online. Hipotesis pada penelitian ini adalah terdapat kaitan coping dan harga diri pada pengungkapan diri dijejaring sosial online.

\section{METODE}

Penelitian ini dilakukan dengan menggunakan metode kuantitatif. Subjek pada penelitian ini adalah 185 siswa-siswi MAN 1 Bojonegoro yang terdiri dari 45 orang siswa $(24,32 \%)$ dan 140 siswi (75,68\%). Teknik pengambilan sampel menggunakan purposive sampling, dengan karakteristik sampel adalah remaja yang menggunakan media sosial. Metode pengumpulan data menggunakan Skala Pengungkapan Diri di Jejaring Sosial Online, Skala Harga Diri, dan Skala Coping.

Skala Pengungkapan Diri di Jejaring Sosial Online digunakan untuk mengukur pengungkapan diri, yaitu kecenderungan para remaja untuk membagi informasi dirinya sehingga dapat diketahui oleh orang lain di jejaring sosial online. Pengungkapan dalam bentuk negatif atau positif, bentuk negatif seperti marah, kesal, sedih, bentuk positif seperti bahagia, senang, motivasi. Sedangkan intensitas pengungkapkan diri dapat dilihat dari tinggi atau rendah di jejaring sosial online.

Skala yang digunakan peneliti adalah Skala Wheeless Revised Self-Disclosure Scale (RSDS) yang dirancang oleh Wheeless dan Grotz (1976). Kemudian diadaptasi oleh 
Bailey (2014) terdiri dari 18 aitem dengan skor alpha 0,76 sampai 0,70. Terdapat dua aspek yaitu kedalaman dan keluasan. Uji validitas konstruk telah dilakukan oleh Bailey (2014) menghasilkan model-model pengungkapan diri. Pada penelitian ini nilai cronbach alpha sebesar $\alpha=0,709$. Contoh aitem pada Skala Pengungkapan Diri di Jejaring Sosial Online adalah "Saya membuat status di jejaring sosial tanpa memiliki tujuan".

Skala Harga Diri digunakan untuk mengukur harga diri yang secara operasional didefinisikan sebagai penilaian subjek terhadap diri sendiri di jejaring sosial online. Remaja yang memiliki harga diri dapat diketahui dari remaja yang memilki penghormatan terhadap diri dan memiliki penerimaan diri. Skala harga diri dalam penelitian ini menggunakan skala harga diri Self Esteem Scale yang dibuat oleh Rosenberg (1965). Peneliti memilih Self Esteem Scale (Rosenberg, 1965) karena instrumen ini mengukur self esteem secara global dan memang ditujukan untuk remaja khususnya bagi para siswa sekolah. Total aitem dalam skala Self Esteem Scale berjumlah 10 aitem dengan aspek penghormatan diri dan penerimaan diri. Reliabilitas Guttman yang dilaporkan adalah $r_{x x}{ }^{1}=0,92$. Sedangkan untuk versi adaptasi berbahasa Indonesia, mempunyai koefisien korelasi aitem-skor total yang berada antara 0,415-0,703 bagi kesepuluh aitem dalam skala $(n=71)$, sedangkan koefisien tes ulang dengan tenggang waktu satu hari menghasilkan $r_{x x}{ }^{1}=0,8587$, namun Martaniah (1991) menemukan koefisien alpha untuk skala ini hanya $0,439 \quad(n=300)$ (Azwar, 2012). Pada penelitian ini peroleh koefisien korelasi aitem-skor total yang berada antara 0,462-0,503. Adapun nilai Cronbach alpha sebesar $\alpha=0,739$ Berikut merupakan contoh aitem Skala Harga Diri, "Saya orang yang gagal".

Skala coping digunakan untuk mengukur kecenderungan penyelesaian masalah yang dilakukan para remaja untuk menghadapi dan mengantisipasi suatu masalah dengan bentuk penyelesaian problem focused coping atau emotion focused coping di jejaring sosial online. Aspek remaja dengan problem focused coping dilihat dari konfrontasi, pencarian dukungan sosial, perencanaan penyelesaian masalah. Sedangkan indikasi emotion focused coping dilihat dari kontrol diri, menjauh, penilaian secara positif, penerimaan tanggung jawab, menghindar, dan mencari dukungan sosial. Skala Coping dalam penelitian ini menggunakan The Frech Ways of Coping Cheklist (WCC-R). Terdiri dari 27 aitem yang berasal dari Lazarus dan Folkman's kemudian diadaptasi oleh Vitaliano, dkk. (1985) yang digunakan dalam penelitiannya pada 425 mahasiswa kedokteran. Reliabilitas dalam skala ini terbagi menjadi tiga, alpha emosi fokus coping sebesar 0,76, alpha untuk problem focused coping adalah 0,79 dan alpha mencari bantuan adalah 0,69 (Cousson-Gelie,dkk., 2010). Cousson-Gelie,dkk (2010) dalam penelitiannya menyarankan bahwa subscale ini membutuhkan perbaikan. Maka dari itu peneliti menggunakan aspek Lazarus dan Folkman (1984) kemudian mendesain menjadi dua aspek, yaitu: problem focused coping dan emotion focused coping. Jumlah aitem tidak berubah tetap berjumlah 27 . Berikut merupakan contoh aitem strategi coping, "Saya mencoba melupakan masalah yang membebani saya". Analisis data dalam penelitian ini menggunakan analisis regresi.

\section{HASIL DAN PEMBAHASAN}

Hasil uji statistik deskriptif menunjukkan bahwa secara keseluruhan pengungkapan diri di jejaring sosial online, harga diri dan coping berada pada kategori tinggi. Hal ini di dapat karena skor mean hipotetik lebih rendah dibandingkan dengan mean empirik sehingga dapat dikatakan secara umum tinggi. Adapun penjelasan dijelaskan pada Tabel 1.

Berdasarkan hasil analisis didapatkan bahwa coping dan harga diri secara 
bersama-sama memiliki pengaruh terhadap pengungkapan diri remaja dijejaring sosial online. Hasil regresi menunjukkan bahwa coping dan harga diri berkorelasi secara signifikan terhadap pengungkapan diri remaja di jejaring sosial online $(F=7,506 ; p$ $<0,05)$. Kedua variabel $X$ tersebut memberikan kontribusi sebesar $\left(R^{2}=0,111\right)$ atau dengan kata lain $11 \%$. Adapun pengaruh per variabel terhadap pengungkapan diri di jelaskan pada Tabel 2.

Tabel 1.

Hasil Uji Statistik Deskriptif

\begin{tabular}{ccccccc}
\hline & \multicolumn{3}{c}{ Hipotetik } & & Empirik \\
& Max & Min & Mean & Max & Min & Mean \\
\hline $\begin{array}{c}\text { Pengungkapan } \\
\text { Diri }\end{array}$ & 20 & 5 & 12,5 & 20 & 10 & 15,935 \\
$\begin{array}{c}\text { Harga Diri } \\
\text { Problem }\end{array}$ & 20 & 5 & 12,5 & 20 & 9 & 14,2216 \\
$\begin{array}{c}\text { Focus coping } \\
\text { Emosi focus } \\
\text { coping }\end{array}$ & 24 & 6 & 15 & 24 & 11 & 18,908 \\
\hline
\end{tabular}

Tabel 2.

Korelasi Parsial Antara Variabel Coping dan Harga Diri

\begin{tabular}{|c|c|c|c|c|c|}
\hline \multicolumn{6}{|c|}{ Koefisien } \\
\hline \multirow[t]{2}{*}{ Model } & \multicolumn{2}{|c|}{$\begin{array}{c}\text { Unstandardized } \\
\text { Coefficients }\end{array}$} & \multirow{2}{*}{$\begin{array}{c}\text { Standardized } \\
\text { Coefficients }\end{array}$} & \multirow[t]{2}{*}{$t$} & \multirow[t]{2}{*}{$p$} \\
\hline & B & $\begin{array}{l}\text { Std. } \\
\text { Error }\end{array}$ & & & \\
\hline \multirow{4}{*}{$\begin{array}{l}1 \text { Problen } \\
\text { Emosi }\end{array}$} & 9,398 & 1,637 & & 5,741 &, 000 \\
\hline & 0,173 & 0,063 & 0,200 & 2,761 & ,006 \\
\hline & 0,207 & 0,088 & 0,223 & 2,349 & ,020 \\
\hline & 0,005 & 0,057 & 0,008 & ,088 & ,930 \\
\hline
\end{tabular}

Tabel 3 menunjukkan bahwa variabel coping (problem focused coping) memberikan kontribusi yang lebih tinggi $(\beta=0,223)$ dibandingkan dengan variabel harga diri $(\beta=0,200)$. Sedangkan, variabel coping (emotion focus coping) tidak memberikan kontribusi $(\beta=0,008)$. Adapun secara parsial variabel harga diri $(t=2,761$, $p=0,006$ ), variabel coping (problem focused coping) $(t=2,349, p=0,02)$ dan variabel coping (emotion focused coping) ( $t$ $=0,088, p=0,93$ ).

Hasil analisis tambahan menunjukkan bahwa pengungkapan diri positif (memotivasi, mengucapkan selamat dan memberikan informasi) berjumlah $68 \%$ dengan jumlah 126 dari 185 responden. Pengungkapan diri negatif (mengeluh, menghina, dan protes) berjumlah $22 \%$ dengan jumlah 40 dari 185 responden, sisanya 10\% (19 dari 185 responden), tidak dapat terkategorikan. Artinya, mayoritas remaja mengungkapkan dalam bentuk positif dijejaring sosial online.

Tabel 3.

Bentuk Pengungkapan Diri Remaja di Jejaring Sosial Online

\begin{tabular}{ccc}
\hline $\begin{array}{c}\text { Bentuk Pengungkapan Diri di } \\
\text { Jejaring Sosial Online }\end{array}$ & Jumlah & Persentase \\
\hline Others & 19 & $10,27 \%$ \\
Pengungkapan Diri Negatif & 40 & $21,62 \%$ \\
Pengungkapan Diri Positif & 126 & $68,11 \%$ \\
\hline Total & 185 & $100,00 \%$ \\
\hline
\end{tabular}

Hasil analisis tambahan juga melihat pengakuan subjek tentang media sosial yang paling banyak digunakan sebagai sarana berjejaring diantara jejaring sosial media yang mereka miliki. Jejaring sosial online terbanyak hasilnya adalah adalah $B B M$ dengan jumlah 114 pengguna, Facebook dengan jumlah 58 pengguna, Instagram dengan jumlah 11 pengguna, LINE dengan jumlah 1 pengguna, dan Twitter dengan jumlah 1 pengguna.

Bentuk pengungkapan diri berdasarkan jejaring sosial online menunjukkan bahwa pengguna Twitter dengan jumlah 0,54\% responden mengungkapkan diri dengan negatif. Pengguna LINE dengan jumlah $0,54 \%$ responden mengungkapkan dengan positif. Pengguna Instagram 1,08\% mengungkapkan diluar dari bentuk positif dan negatif, sedangkan responden 1,08\% mengungkapkan positif dan responden $3,78 \%$ mengungkapkan negatif di Instagram. Pengguna Facebook 4,86\% mengungkapkan diluar bentuk positif dan negatif. Sedangkan $4,86 \%$ responden mengungkapkan negatif dan 21,62\% mengungkapkan positif di Facebook. Pengguna $B B M \quad 4,32 \%$ mengungkapkan 
diluar bentuk positif dan negatif. Sedangkan $\quad 15,1 \% \quad$ responden mengungkapkan negatif dan $42,1 \%$ mengungkapkan positif di $B B M$. Adapun bentuk pengungkapan diri berdasarkan jejaring sosial online dijelaskan Tabel 4.

Tabel 4.

Pengguna Jejaring Sosial Online dengan Bentuk Pengungkapan Diri

\begin{tabular}{|c|c|c|c|}
\hline $\begin{array}{c}\text { Bentuk } \\
\text { Pengungkapan } \\
\text { \& Jejaring } \\
\text { Sosial online }\end{array}$ & $\begin{array}{c}\text { Bentuk } \\
\text { Pengungkapan }\end{array}$ & Jumlah & $\%$ \\
\hline Twitter & Negatif & 1 & $0,54 \%$ \\
\hline \multirow[t]{2}{*}{ Line } & Positif & 1 & $0,54 \%$ \\
\hline & Lainnya & 2 & $1.08 \%$ \\
\hline \multirow{3}{*}{ Instagram } & Positif & 3 & $1,08 \%$ \\
\hline & Negatif & 6 & $3,78 \%$ \\
\hline & Lainnya & 9 & $4,86 \%$ \\
\hline \multirow[t]{3}{*}{ Facebook } & Negatif & 9 & $4,86 \%$ \\
\hline & Positif & 40 & $21,26 \%$ \\
\hline & Lainnya & 8 & $4,32 \%$ \\
\hline \multirow[t]{2}{*}{ BBM } & Negatif & 28 & $15,1 \%$ \\
\hline & Positif & 78 & $42,1 \%$ \\
\hline \multicolumn{2}{|c|}{ Jumlah } & 185 & $100,00 \%$ \\
\hline
\end{tabular}

Hasil penelitian ini menunjukkan bahwa terdapat pengaruh positif harga diri terhadap pengungkapan diri. Secara keseluruhan remaja dengan harga diri rendah semakin tinggi intensitas pengungkapan diri dan lebih negatif pengungkapan diri di jejaring sosial online. Hal ini berbeda dengan penelitian Mulatsih (2015) yang menunjukkan bahwa terdapat hubungan yang positif antara harga diri dengan pengungkapan diri pada remaja saat chatting diinternet. Semakin tinggi harga diri maka semakin tinggi pula pengungkapan diri dan sebaliknya semakin rendah harga diri maka pengungkapan diri remaja juga rendah. Meskipun demikian didapatkan perbedaan yaitu penelitian yang dilakukan oleh Mulatsih (2015) menggunakan media chating di internet yang hanya dapat ditonton oleh sebagian orang tertentu saja, bahkan bisa saja chatting dengan dua orang saja. Berbeda dengan jejaring sosial online yang dapat ditonton oleh jutaan orang yang menggunakan jejaring sosial online dan dapat digunakan untuk membuat status.
Dapat disimpulkan bahwa penelitian yang menggunakan jejaring sosial online berbeda hasilnya dengan penelitian dengan chatting di internet.

Sejalan dengan Mulatsih (2015), Forest dan Wood (2012) dalam penelitiannya menggunakan jejaring sosial online Facebook menunjukkan bahwa hadirnya jejaring sosial online memberikan angin segar bagi para remaja karena jejaring sosial online seperti Facebook dapat membuat kehidupan orang-orang menjadi lebih baik dalam mengalami kesulitan, mengembangkan hubungan sosial interpersonal. Seseorang yang menggunakan Facebook dapat mengungkapkan diri sehingga akan mendorong seseorang dengan harga diri rendah untuk lebih mengekspresikan diri lebih terbuka.

Hal tersebut sama seperti teori modal sosial mengatakan bahwa jejaring sosial online dapat mejadi modal sosial bagi para remaja. Remaja memandang bahwa jejaring sosial online sebagai alat yang tepat untuk meningkatkan harga diri remaja. Jejaring sosial online mempunyai potensi untuk menjadi modal sosial, karena dapat merubah remaja yang mempunyai harga diri rendah menjadi memiliki harga diri tinggi dan lebih produktif. Pengguna yang lebih rendah pada kepuasan hidup dan harga diri rendah akan mengembangkan modal sosial yang lebih tinggi dengan menggunakan Facebook dalam menjalin pertemanan (Ellison,dkk, 2007).

Pada penelitian ini sejalan dengan penelitian di atas menunjukkan bahwa harga diri tinggi akan membuat lebih positif dalam mengungkapkan diri. Hal ini karena pengungkapan diri, baik yang positif maupun yang negarif, dibutuhkan keyakinan pada diri yang baik, pada penelitian ini ditemukan kecenderungan subjek mengungkapkan diri secara positif dibandingkan pengungkapan diri yang negatif. 
Hasil penelitian ini juga menunjukkan adanya pengaruh coping dengan pengungkapan diri. Secara keseluruhan remaja yang mempunyai masalah mengungkapakan di jejaring sosial online. Namun, hal ini berbeda dengan penelitian Tromholt (2016) menunjukkan bahwa Facebook tidak membuat seseorang dapat menyelesaikan masalah. Efek berhenti dari Facebook dapat meningkatkan kesejahteraan dan mengurangi masalah dalam hidup. Hal itu disebabkan karena pengguna Facebook cenderung merasa iri dengan teman-temannya di Facebook.

Hal ini bertentangan dengan hasil penelitian ini. Akan tetapi, alasan yang ditemukan adalah adanya perbedaan usia. Tromholt (2016) menggunakan rata-rata responden berusia 34 tahun. Sedangkan peneliti dan kebanyakan peneliti lainnya menggunakan responden rata-rata adalah remaja berusia 14 - 17 tahun (Ritonga \& Andhika, 2012; Sherlyanita \& Rakhmawati, 2016). Hal tersebut juga dikuatkan oleh Arseneault (2012) dalam penelitianya menggunakan usia 17 - 25 tahun menemukan hal yang sama dengan peneliti bahwa seseorang dengan kecemasan dan tekanan yang tinggi lebih besar mengungkapkan diri menggunakan jejaring sosial online Facebook sebagai media untuk mengatasinya. Sedangkan seseorang yang bahagia, kurang sering menggunakan jejaring sosial online Facebook.

Pada penelitian ini usia subjek antara 14 17 tahun karena dinilai pada masa ini remaja dituntut untuk mencapai hubungan yang baru dan lebih matang dengan teman sebaya dari kedua jenis kelamin (Bahruddin, 2014). Hal tersebut sejalan dengan manfaat pengungkapan diri karena dapat memperkuat rasa suka dan mengembangkan hubungan (Taylor, Peplau, Sears, 2012). Maka dari itu kebiasaan para remaja mengungkapakan diri memang tidak bisa dihilangkan. Ditambah dengan hadirnya jejaring sosial online membuat remaja lebih membuka dirinya secara online dibandingkan secara langsung (Santrock, 2012).

Hasil penelitian menyebutkan bahwa secara keseluruhan remaja yang memilki harga diri tinggi mengungkapkan diri dengan intensitas rendah di jejaring sosial online. Artinya, remaja dengan harga diri tinggi dapat mengatasi kesepian, kecemasan, penolakan sosial dan kontrol sosial (Sarwono \& Meinarno, 2015; Misnani, 2016). Beruntung sekali remaja yang mempunyai harga diri tinggi karena mempunyai kontrol diri yang bagus, nyaman dengan dirinya, keberhasilan, pencapaian, dan penyesuaian diri yang baik. Hal ini membuat remaja tidak akan mengungkapkan diri secara impulsif di jejaring sosial online dan lebih mengungkapkan diri dalam bentuk positif di jejaring sosial online. Jika ditinjau dalam teori Erikson menyebut masa remaja sebagai masa dimana harus memutuskan siapakah dirinya, bagaimana dirinya, tujuan apa yang kelak diraihnya. Biasa dikenal dengan tahap identitas versus kebingungan identitas (Santrock, 2012). Remaja dituntut untuk menemukan siapa dirinya, menempati peran baru dalam keluarga bahkan lingkungan. Erikson menyebutkan bahwa jika para remaja dapat melewatinya dengan cara sehat dan sampai pada suatu jalur yang positif untuk diikuti maka remaja mendapatkan identitas yang positif. Sedangkan identitas positif atau negatif meliputi para remaja menilai dirinya sendiri. Penilaian atau evaluasi secara positif ataupun negatif disebut dengan harga diri (Sarwono \& Meinarno, 2015).

Berbeda dengan remaja yang memiliki harga diri tinggi, remaja dengan harga diri rendah menurut Erikson karena tidak berhasil mengatasi krisis identitas dan menderita kebingungan identitas. Kebingungan identitas yang dialami membuat para remaja menarik diri, mengisolasi diri, atau bahkan melebur dalam dunia kawan sebaya dan kehilangan identitas di tengah perkumpulan. Bahkan 
tidak hanya itu saja maraknya kasus garagara membuat status kemudian dipenjara, mudahnya terprovokasi, memposting foto bugil, meng-upload video porno, dan pertikaian antar kelompok karena hanya status. Semuanya adalah bentuk dari tidak bisanya remaja dalam mengontrol pengungkapan dirinya di jejaring sosial online. Hal tersebut merupakan gejalagejala seseorang mempunyai harga diri rendah, kesehatan fisik dan mental yang rendah, prospek ekonomi yang buruk, perlaku kriminal yang tinggi cenderung memilki harga diri yang rendah menurut (Trzesniewski, dalam Santrock, 2012).

Peran harga diri memang tidak bisa dipungkiri pada remaja, penelitian ini menegaskan bahwa secara keseluruhan remaja dengan harga diri rendah perlu adanya intervensi sebagai tindak lanjut untuk penguatan harga diri guna menjadikan perilaku remaja yang lebih sehat di dunia virtual . Menguatkan penilaian pada remaja terhadap dirinya agar lebih positif dan menyadari dampak dari pengungkapan diri di jejaring sosial online. Sehingga remaja dengan harga diri rendah lebih bisa mengontrol dan semakin cerdas dalam mengungkapkan diri di jejaring sosial online. Tidak hanya itu, remaja yang mempunyai harga diri tinggi, mereka akan lebih memikirkan risiko sebelum mengungkapkan diri di jejaring sosial online seperti pengabaian, penolakan, hubungan kontrol, pengkhianatan.

Pentingnya resiko mengungkapkan diri pada para remaja memang harus dipertimbangkan sebelum mengungkapakan diri di jejaring sosial online. Maka dari itu, peran harga diri sangat penting pada remaja dalam mengungkapkan diri di jejaring sosial online. Meskipun dimasa remaja, Hall (dalam Santrock, 2012) menyebutkan masa badai dan stres, masa bergolak yang diwarnai oleh konflik dan perubahan suasana hati. Akan tetapi dalam berjejaring sosial online perlu adanya kesadaran tentang bahayanya pengungkapan diri. Seperti hasil penelitian ini menunjukkan bahwa meskipun secara keseluruhan remaja menggunakan coping (Emotion Focused Coping) dalam aktivitas sehari-hari. Akan tetapi, dalam berjejaring sosial online para remaja lebih menggunakan coping (Problem Focused Coping). Sehingga para remaja mengungkapkan diri mejadi lebih positif di jejaring sosial online dan bijaksana dalam memilah.

Dapat disimpulkan bahwa para remaja dengan harga diri rendah memerlukan intervensi agar dapat menilai atau mengavaluasi dirinya lebih positif sehingga para remaja lebih mempunyai harga diri tinggi. Sedangkan untuk coping, remaja diharapkan untuk meyelesaikan masalah dijejaring sosial online dengan bentuk positif. Merujuk pada hasil penelitian ini yang menujukkan bahwa coping dan harga diri secara bersama-sama mempengaruhi pengungkapan diri dijejaring sosial online semakin tinggi harga diri maka semakin rendah intensitasnya dijejaring sosial online.

\section{SIMPULAN}

Hasil penelitian ini secara umum menunjukkan bahwa harga diri dan coping mempunyai korelasi yang kuat dalam pengungkapan diri pada remaja. Hasil penelitian ini mengimplikasikan bahwa penguatan kapasitas soft skill dalam hal ini harga diri dan kemampuan memilih menyelesaian masalah pada remaja menjadi suatu yang penting untuk mengurangi problem perilaku remaja di jejaring sosial online. Pengembangan perilaku berjejaring sosial bisa menjadi materi yang diajarkan melalui intra maupun ekstrakulikuler di sekolah untuk menjadi pribadi yang cerdas dalam berjejaring sosial online.

\section{DAFTAR PUSTAKA}

Ariani, M., Elita, V., \& Zulfitri, R. (2013). Hubungan intensitas pengguna 
jejaring sosial terhadap kualitas tidur remaja di SMA 3 SIAK. Naskah Publikasi. Ilmu Keperawatan Universitas Riau. Diakses dari http://repository.unri. ac.id/xmlui/handle/123456789/428.

Arsenault. J. M. (2012). The role of attachment in young adults use of facebook for strategi coping (Disertasi tidak dipublikasikan). University of Windsor Canada.

Azwar, S. (2012). Reliabilitas dan validitas edisi keempat. Yogyakarta: Pustaka Pelajar.

Baharuddin. (2014). Pendidikan dan psikologi perkembangan. Yogyakarta: Ar-Ruzz Media.

Bailey, L. (2014). Disclosure decision model: Analysis of private and workplace friendships. Thesis. Wake Forest University Graduate School of Arts And Sciences Winston-Salem.

Berita Satu.com. (2015). Diunduh dari http://www.beritasatu.com/iptek/27 5905-58-anak-di-indonesia-tidakmemahami-cyber-bullying.html. Diakses 14 September 2016.

Buntaran, F. A. A. \& Helmi, A. F. (2015). Peran kepercayaan interpersonal remaja yang kesepian dalam memoderasi pengungkapan diri pada media jejaring sosial online. Gadjah Mada Journal of Psychology, 1(2), 106-119.

Cousson-Gelie, F., Cosnefroy, O., Christophie, V., Segrestan-Crouzet, C., Merckaert, I., Fournier, E., Libert, Y., Lafaye, A \& Razavi., D. (2010). The ways of strategi coping checklist (WCC): Validation in French-speeking cancer patients. Journal of Health Psychology, $\begin{array}{lcl}15(8), \quad 1246-1256 . & \text { doi: } \\ 10.1177 / 1359105310364438 .\end{array}$

Dhani, K. R. (2015). Hubungan pengguna facebook dengan narsisme, self esteem dan kesepian pada remaja di Indonesia. Naskah Publikasi. Diakses dari http://kurniarahmad_ dhani.web.ugm.ic.id

Ellison, N. B., Steinfield, C. \& Lampe, C. (2007). The benefits of facebook "friends" social capital and college students' use of online social network sites. Journal of ComputerMediated Communi-cation, 12(4), 1143-1168. doi: 10.1111/j.10836101.2007.00367.x

Forest, A. L. \& Wood, J. V. (2012). When social networking is not working: Individuals with low self esteem recognize but do not reap the benefit of self disclosure on facebook. Publication Types, University of Waterloo, Canada, 23(3), 295-302.

Gainau, B. M. (2008). Pengembangan inventori self disclosure bagi siswa usia sekolah menangah atas. Jurnal Ilmu Pendidikan, 15(3), 168-174.

Griffiths, M. D. (2000). Internet addictiontime to be taken seriously?. Addiction Research, 8, 413-418.

Hogben, G. (2007). Security issues and recommendations for online social networks, ENISA Position Paper No.1,http://www .enisa.europa.eu/d oc/pdf/deliverables/enisa_pp_social _networks.pdf

Kuss, D., \& Griffiths, M. (2011). Online social networking and addiction: A review of the psychological literature. Int $J$ Environ Res Public Health, (8), 3528-3552. doi: 10.3390/ijerph8093528. 
Lazarus, R. S. \& Folkman, S. (1984). Stress appraisal, and strategi coping. New York: $\quad$ Springer Publishing Company.

Madden, M., Lenhart, A., Duggan, M., Cortesi, S. \& Gasser, U. (2013). Teens and technology. Pew Research Center. Washington DC. Diakses pada tanggal 5 November 2016 dari http://www.pewinternet.org.

Reports

2013/Teens-andTech.Aspx.

Martaniah, S. M. (1991). Psikologi abnormal. Yogyakarta: Yayasan Penerbit Fakultas Psikologi UGM.

Misnani, J. (2016). Hubungan perilaku asertif dan kesepian dengan kecemasan sosial korban bullying pada siswa SMP Negeri 27 Samarinda. Psikoborneo, 4(4), 793 -803 .

Mulatsih, T. (2015). Hubungan self esteem dengan self disclosure pada remaja saat chatting di internet. Skripsi. Universitas Islam Negeri Sunan Kalijaga Yogyakarta.

Paramithasari, P. P. \& Dewi, K. E. (2013). Hubungan antara kontrol diri dengan pengungkapan diri di jejaring sosial pada siswa SMA Kesatrian 1 Semarang. Journal Empati, 2 (4).

Ritonga, S. \& Andhika, W. (2012). Pengaruh media komunikasi internet terhadap pola perilaku anak di bawah 17 tahun. Jurnal Ilmu Sosial-Fakultas Isipol Uma, 5(2), 94-100.

Rosenberg, M. (1965). Society and the adolescent self-image. Princeton: Princeton University Press.
Santrock, J.W. (2007). Remaja jilid 2. (edisi 11). Jakarta: Erlangga.

Santrock, J. W. (2012). Life span development: Perkembangan masa hidup jilid 1. Jakarta: Erlangga.

Sarwono, W. S. \& Meinarno, A.E. (2015). Psikologi sosial. Jakarta: Salemba Humanika.

Sherlyanita, A. K. \& Rakhmawati, N.A. (2016). Pengaruh dan pola aktivitas penggunaan internet serta media sosial pada siswa SMPN 52 Surabaya. Journal of Information Systems Engineering and Business Intelligence, 2(1), 17-22.

Taylor, E. S., Peplau, A. L. \& Sears, O. D. (2012). Psikologi sosial. Jakarta: Karisma.

Tromholt, M. (2016). The facebook experiment: Quitting facebook leads to higher levels of well-being. Cyberpsychology, Behavior, and Social Networking, 19(11), 661-666. doi: 10.1089/cyber.2016.0259

Varnali, K. \& Toker, A. (2015). Self disclosure on social networking sites. Journal Social Behaviour and Personality, 43(1), 1-4.

Vitaliano, P. P., Russo, J., Carr, J. E. Maiuro, R. D \& Becker, J. (1985). The ways of coping checklist: Revision and psychomeric properties. Multivariate Behavior Research, 20(1), 3-26.

Wheeless, L. R., \& Grotz, J. (1976). Conceptualization and measurement of reported self- disclosure. Human Communication Research, 2, 338346. 